\title{
Resistance to neck blast caused by Pyricularia oryzae in Italian rice cultivars
}

\author{
Patrizia Titone • Gabriele Mongiano • \\ Luigi Tamborini
}

Accepted: 16 December 2014 /Published online: 4 January 2015

(C) The Author(s) 2015. This article is published with open access at Springerlink.com

\begin{abstract}
Very little information is available on neck blast resistance in Italian rice varieties under field conditions. In order to provide these data, 105 cultivars were tested under very favourable conditions for the disease development; the cultivars' response to a single treatment of tricyclazole was also evaluated. Among tested varieties, $15 \%$ showed resistance to the disease, $17 \%$ moderate resistance, $30 \%$ moderate susceptibility and $38 \%$ susceptibility. Generally, recently developed cultivars were more tolerant to neck blast, compared to the oldest ones. Furthermore, cultivars with Long A grain shape are the most susceptible to neck blast, followed by medium grain type, round grain and Long B grain shape. A single spray of tricyclazole (450 a.i. $\mathrm{g} / \mathrm{ha}$ ) was effective in reducing disease incidence $(55 \%$ average reduction). It was also observed that there was a reduction in severity of symptoms. The majority of rice Italian cultivars are susceptible to neck blast disease. This study underlines the importance of field tests as useful tool for researchers, breeders and growers, combining scientific value with impact in application, giving valuable information to improve disease control.
\end{abstract}

Keywords Neck blast - Oryza sativa - Variety . Resistance $\cdot$ Disease incidence $\cdot$ Tricyclazole

P. Titone $(\bowtie) \cdot G$. Mongiano $\cdot$ L. Tamborini Agricultural Research Council, Centro di sperimentazione e certificazione delle sementi,

Vercelli, Strada Statale 11 per Torino $\mathrm{km} \mathrm{2.5,}$ 13100 Vercelli, Italy

e-mail: patrizia.titone@entecra.it

\section{Introduction}

Italian rice culture represents $55 \%$ of the entire European Union's production (Casati 2013) and comprises more than $50 \%$ of the rice cultivars listed in the "Common catalogue of varieties of agricultural plant species" (206 varieties out of 384) (Commission 2013). In 2012, the area planted to rice in Italy was 235051.96 ha; a slight reduction of such area $(-8 \%$ ) was recorded in 2013 (Ente Nazionale Risi 2013).

Rice blast, caused by Magnaporthe oryzae B. Couch (anamorph Pyricularia oryzae Cavara) (Couch and Kohn 2002), is considered a major disease of rice because of its wide geographic distribution and destructiveness under favorable conditions (IRRI 2013). A disease resembling blast was described in Italy in 1775 (Gallo 1775) in a treatise on rice cultivation and agriculture. For almost three centuries, under the name of "Brusone", several plant diseases that cannot all be attributable to $M$. oryzae were mentioned. In 1828 was published a book about blast disease and the farming techniques for its management (Astolfi 1828). In Northern Italy, documented epidemics attributed to this pathogen occurred from 1820 to $1827(\operatorname{Re} 1826)$ and thereafter for twenty consecutive years, from 1875 to 1895 , in all cultivated areas. It is important to note that blast disease induced the development of Italian rice cultivars over the centuries (Buffa 2000).

Symptoms can develop on the whole plant (TeBeest et al. 2007; Faivre-Rampant et al. 2011; Faivre-Rampant et al. 2013) but, in Italy, environmental conditions for rapid growth of the pathogen mainly occur between the second half of July and the first 10 days of August 
(Rodolfi et al. 2006); for this reason, the most severe outbreaks are observed starting from inflorescence emergence stage and eventually show neck blast symptoms (Cortesi and Giuditta 2003). When severely affected, rice display both yield and quality reduction (Moletti et al. 1988). Losses in grain and milling yields (rate of polished white rice obtained from unhusked rough rice) can vary from minimal to $85 \%$ of production depending on inoculum pressure, crop growth stage at the time of infection, environmental conditions, cultivar resistance and agronomic practices (IRRI 2013). Milling yield strongly affects economic aspects. In Italy, a significant reduction in milling yield (e.g., $20 \%$ ) may lead to a decrease up to $50 \%$ of the market value (unpublished data).

Most evaluations of blast resistance under field conditions are made at the nursery stage following the International Rice Research Institute Standard Evaluation System (IRRI-SES) (IRRI 2002; Aram et al. 2013; Shafaullah et al. 2011; Marchetti 1983), which provides data in a relatively short time, since this method does not require cultivation until ripening stage. This method, however, is not always representative of what happens at the time of heading or later, when blast can infect the neck and directly compromise yield (Webster and Gunnell 1992). In a long term study carried out from the Ente Nazionale Risi under Italian field conditions (19 years), leaf blast assessments underestimated neck blast disease in $12 \%$ of cases (Biloni and Lorenzi 2002).

Disease management is based mainly on efficient use of nitrogen fertilization (Webster and Gunnell 1992; Long et al. 2000), use of resistant cultivars, crop rotation, maintaining a proper flood level and treatment with fungicides (TeBeest et al. 2007; Maciel 2011). Surveys conducted in 2009 showed that in Italy the $75 \%$ of the rice area is treated against blast disease and the $94 \%$ of treated surface is treated with tricyclazole, mainly by a single treatment (Di Tullio and Baldi 2011). Tricyclazole is a systemic fungicide commercialized since 1970s (Froyd et al. 1976) and registered in Italy in the 1998; in 2008 the Commission of European Communities approved the withdrawal of authorizations for plant protection products containing that active ingredient. In order to firstly evaluate the resistance of Italian rice cultivars to neck blast disease and then the response of cultivars to a single treatment of tricyclazole against neck blast disease in Northern Italy (with a view to its possible future inclusion in Annex I to Directive 91/414/EEC), we tested 105 cultivars registered in
Italian Rice Catalogue, representing the $98 \%$ of the cultivated rice area in 2012. Cultivars were chosen among those traditionally most important registered in National list before 2005 (Tamborini and Legnani 2005), and all cultivars registered from 2005 to 2013 (SIAN 2013).

\section{Materials and methods}

Trials were performed during 2011 and 2012 on Olai farm (45 $16^{\prime}$ N $8^{\circ} 39^{\prime}$ W, 109 m a.s.1., Ceretto Lomellina, Lombardy Region), in the main area of rice cultivation in Italy. The chosen location has a long history of strong neck blast disease presence and has sandy soil. Sowing was done on dry soil, on 5 May 2011 and on 7 May 2012 with pneumatic seed drill. Once rice reached the 3rd leaf stage, the field was permanently flooded until beginning of the ripening stage. High rates of nitrogen fertilizer were applied 3 times, twice between 3rd leaf unfolding and tillering stage $\left(210 \mathrm{~kg} \mathrm{ha}^{-1}\right.$ of $46 \%$ urea applied two times, equal to $97 \mathrm{~kg} \mathrm{~N} \mathrm{ha}^{-1}$ per application) and after stem elongation (300 kg ha ${ }^{-1}$ of 13-5-20 mineral complex equal to $39 \mathrm{~kg} \mathrm{~N} \mathrm{ha}^{-1}$ ).

\section{Plant material}

A total of 105 varieties belonging to different commercial groups (Round, Medium, Long A and Long B) were evaluated for panicle blast resistance under flooded field conditions. Product category with Long A grain was further divided into "parboiled" grain (LA-PB) and "internal consumption" grain (LA-IC). The latter refers to those varieties that are marketed almost exclusively in Italy for the preparation of "risotto". Varieties were chosen from among the most important Italian cultivars; they represent the $98.4 \%$ of the Italian cultivated area in 2012 (Tables 2, 3, 4 and 5).

\section{Experimental design}

A randomized split plot design was used, consisting of four replicates of treated and untreated plot. These main plots were split among the 105 varieties. The experimental unit was a 2-m row; distance between rows was $20 \mathrm{~cm}$; tested rows were interspersed with rows of a highly blast-susceptible Italian rice cultivar, "Deneb", used as "spreader" row. 
Evaluation for blast resistance

Rice cultivars were classified on the base of incidence (percentage of infected panicles) and severity (part of panicle exhibiting blast symptoms) of the disease, evaluated in untreated block 3 weeks after heading. Based on the incidence rates of panicles exhibiting neck blast symptoms, cultivars were classified as follow: Resistant (R) with 0 to $15 \%$ of infected panicles, Moderately Resistant (MR) with 15.1 to $30 \%$, Moderately Susceptible (MS) with 30.1 to $50 \%$, and Susceptible (S) with 50.1 to $100 \%$ (Puri et al. 2009). Severity of symptoms was rated on infected panicles using a 0 to 9 ordinal scale (IRRI 2002), where: 0 indicates no lesions or lesions only on pedicels, 1 indicates lesions on several pedicels or secondary branches, 3 indicates lesions on a few primary branches or the middle part of panicle axis, 5 indicates lesions partially around the base or the uppermost internode or the lower part of panicle axis, 7 refers to a lesion completely around panicle base or uppermost internode or panicle axis near base with more than $30 \%$ of filled grains, 9 indicates lesions completely around panicle base or uppermost internode or the panicle axis near the base with less than $30 \%$ of filled grains. Symptom scores were attributed as average symptom observed in each experimental unit. Cultivar Vialone Nano was used as susceptible control and two varieties were considered as resistant control: cv. Arsenal and cv. CLXL745. Leaf blast was not recorded as it was not sufficiently developed.

Evaluation of treatment with tricyclazole

A single spray of tricyclazole at the recommended rate ( $450 \mathrm{~g} / \mathrm{ha}$ of tricyclazole, corresponding to $0.6 \mathrm{~kg} / \mathrm{ha}$ of Beam 12) was applied at the flowering stage to treated plots; the other plots were used as untreated control. Effect of fungicide treatment was evaluated comparing the average of panicle blast incidence obtained in treated and untreated block.

Data analysis

Incidence rates were subjected to a multi factorial ANOVA, after angular transformation ( $\mathrm{Y}=\operatorname{arcsine}$ $\mathrm{p}^{0.5}$ ). The model included: treatment, cultivar, block, year, cultivar-year interaction, treatment-year interaction and cultivar-treatment interaction. Furthermore, after founding significant differences between cultivars,
LSD (with Bonferroni correction) was calculated for comparison of cultivar incidence means. Since there is an equal number of observation per group, a single value was calculated. Statistical analysis was performed using SPSS software (version 21.0 for PC) and Microsoft Excel 2013.

\section{Results}

Effects of cultivar, treatment and year were statistically significant at the 0.05 significance level (Table 1). As indexed by the $\mathrm{R}^{2}$ statistic, this multi-factorial ANOVA accounted for $74 \%$ of the total variation in the incidence variable.

Variability in panicle blast resistance

Tested cultivars were evaluated in untreated block for panicle blast incidence and severity and separated in resistance classes (Tables 2, 3, 4 and 5). The ANOVA showed significant differences in incidence of diseased panicles among cultivars, $(p<0.001)$.

Only two cultivars were asymptomatic; $15 \%$ of tested cultivars were Resistant, $17 \%$ Moderately Resistant, $30 \%$ Moderately Susceptible, and $38 \%$ Susceptible. Cultivar CLXL745, used as resistant control, was confirmed to be highly resistant and in both years of test it was asymptomatic. Cultivar Arsenal, also considered as resistant control, was placed in the resistant class with $8 \%$ of infected panicles, showing slight lesions. Cultivar Vialone Nano, used as susceptible control, was severely infected by the pathogen ( $98 \%$ incidence), confirming that it is a highly susceptible cultivar that, without disease management can lose the whole yield.

Table 1 Results of the multi factorial ANOVA performed on incidence rates with alpha $=0.05$

\begin{tabular}{llll}
\hline Source of variation & df & F & Sig. \\
\hline Cultivar & 104 & 21.45 & .000 \\
Block & 3 & 67.95 & .000 \\
Treatment & 1 & 777.41 & .000 \\
Year & 1 & 4.70 & .030 \\
Cultivar * Year & 104 & 3.61 & .000 \\
Treatment * Year & 1 & 0.24 & N.S. \\
Cultivar * Treatment & 104 & 2.26 & .000 \\
\hline
\end{tabular}


Table 2 List of Resistant varieties (R), with 0-15.0\% incidence of panicles showing neck blast symptoms; results expressed as average of incidence and severity score assessed in 2011 and 2012 in treated and untreated plots

\begin{tabular}{|c|c|c|c|c|c|c|c|c|}
\hline \multirow[t]{2}{*}{ Cultivar } & \multicolumn{2}{|l|}{ Untreated } & \multicolumn{2}{|l|}{ Treated } & \multirow{2}{*}{$\begin{array}{l}\text { Mean } \\
\text { Incidence }^{a}\end{array}$} & \multirow{2}{*}{$\begin{array}{l}\text { Registration } \\
\text { year }\end{array}$} & \multirow{2}{*}{$\begin{array}{l}2012 \\
\text { area }^{b} \\
\text { (ha) }\end{array}$} & \multirow{2}{*}{$\begin{array}{l}\text { Grain } \\
\text { shape }\end{array}$} \\
\hline & $\begin{array}{l}\text { Incidence } \\
(\%)\end{array}$ & $\begin{array}{l}\text { Severity } \\
(0-9)\end{array}$ & $\begin{array}{l}\text { Incidence } \\
(\%)\end{array}$ & $\begin{array}{l}\text { Severity } \\
(0-9)\end{array}$ & & & & \\
\hline CL46 & 0 & 0 & 0 & 0 & 0.00000 & 2012 & 59 & Long B \\
\hline CLXL745 & 0 & 0 & 0 & 0 & 0.00000 & 2011 & 1302 & Long B \\
\hline Libero & 1 & 1 & 1 & 0 & 0.04022 & 2005 & - & Long B \\
\hline Atlantis & 2 & 1 & 4 & 2 & 0.08329 & 2006 & 11 & Long B \\
\hline Oceano & 3 & 2 & 0 & 0 & 0.04307 & 2012 & 43 & Long B \\
\hline CL71 & 4 & 1 & 4 & 2 & 0.09817 & 2011 & 16,986 & Long B \\
\hline Wang & 6 & 4 & 4 & 3 & 0.16373 & 2013 & 22 & Medium \\
\hline CRW3 & 7 & 4 & 9 & 2 & 0.18147 & 2007 & - & Round \\
\hline Mare CL & 8 & 1 & 1 & 0 & 0.08357 & 2012 & 906 & Long B \\
\hline Arsenal & 8 & 3 & 3 & 1 & 0.15249 & 2008 & 933 & Long B \\
\hline Teseo & 9 & 3 & 1 & 0 & 0.12553 & 2012 & - & Long B \\
\hline CL26 & 9 & 3 & 6 & 3 & 0.23562 & 2011 & 5653 & Long B \\
\hline Sagittario & 11 & 2 & 5 & 2 & 0.19758 & 2012 & 13 & Long B \\
\hline Vulcano & 13 & 4 & 6 & 2 & 0.21292 & 2010 & 6 & Long A (IC) \\
\hline Falco & 13 & 3 & 9 & 4 & 0.26279 & 2012 & 6 & Long A (IC) \\
\hline CL80 & 13 & 3 & 3 & 0 & 0.15249 & 2012 & 214 & Long B \\
\hline
\end{tabular}

${ }^{\text {a }}$ Mean calculated after angular transformation. $\mathrm{LSD}=0.39964$

${ }^{\mathrm{b}}$ Italian Cultivated Area in 2012. Data provided by Ente Nazionale Risi

The most widely cultivated cultivars within the $\mathrm{R}$ and MR groups are CL71 (Long B), Luna CL (LA-PB) and CL26 (Long B); they represent $13 \%$ (30471 ha) of the cultivated area, they are resistant to imidazolinone herbicides (Clearfield ${ }^{\circledR}$ technology) and they have been recently registered (2011). Within the R and MR cultivars 4 out of 34 varieties belong to LA-IC grain shape group and only one, Roma, an historical variety released in the market in 1931, is cultivated on a significant area (3840 ha). In MS group, the three most cultivated varieties have a LA-IC grain shape: S. Andrea (10796 ha), Carnaroli (9003 ha) and Karnak (7796 ha). No Clearfield $^{\circledR}$ varieties resulted MS. Almost $60 \%$ of the Italian rice production area is cultivated with susceptible varieties; adding Moderately Susceptible cultivars the involved area reaches $80 \%$. In fact, the three most cultivated varieties in 2012, Centauro, Volano and Sirio CL, resulted Susceptible and, despite this characteristic, they are extensively cultivated for their agronomic characteristics and, respectively, for high yield, organoleptic qualities or resistance to imidazolinone herbicides. Furthermore, Sirio CL is the only
Clearfield ${ }^{\circledR}$ variety classified Susceptible (S) to neck blast.

The $88 \%$ of LA-PB grain shape cultivars were Moderately Susceptible or Susceptible, followed by Medium grain shape (80\%), LA-IC grain shape (78 \%), Round grain shape (68\%), and Long B grain shape (37\%) (Fig. 1).

Dividing cultivars depending on the year of registration on Italian catalogue of rice varieties and calculating average incidence and severity in untreated block, we observed that the most recently developed cultivars are more resistant to the disease. In fact, mean incidence (\%) and severity ( $0-9$ scale) for the varieties bred before 1970 s is $71 \%$ and 8 respectively, instead of cultivars registered after 2010 , which have $30 \%$ mean incidence and an average of severity score of 5 (Table 6).

\section{Treatment effect}

Treatment with tricyclazole at the flowering stage significantly reduced incidence of diseased panicles (55\% mean reduction) $(p<0.001)$. It also reduced severity of 
Table 3 List of Moderately Resistant varieties (MR), 15.1-30.0\% incidence of panicles showing neck blast symptoms; results expressed as average of incidence and severity score assessed in 2011 and 2012 in treated and untreated plots

\begin{tabular}{|c|c|c|c|c|c|c|c|c|}
\hline \multirow[t]{2}{*}{ Cultivar } & \multicolumn{2}{|l|}{ Untreated } & \multicolumn{2}{|l|}{ Treated } & \multirow{2}{*}{$\begin{array}{l}\text { Mean } \\
\text { Incidence }^{\mathrm{a}}\end{array}$} & \multirow{2}{*}{$\begin{array}{l}\text { Registration } \\
\text { year }\end{array}$} & \multirow{2}{*}{$\begin{array}{l}2012 \\
\text { area }^{b} \\
\text { (ha) }\end{array}$} & \multirow{2}{*}{$\begin{array}{l}\text { Grain } \\
\text { shape }\end{array}$} \\
\hline & $\begin{array}{l}\text { Incidence } \\
(\%)\end{array}$ & $\begin{array}{l}\text { Severity } \\
(0-9)\end{array}$ & $\begin{array}{l}\text { Incidence } \\
(\%)\end{array}$ & $\begin{array}{l}\text { Severity } \\
(0-9)\end{array}$ & & & & \\
\hline Orione & 16 & 4 & 4 & 1 & 0.22154 & 2010 & 82 & Medium \\
\hline Elettra & 16 & 2 & 9 & 1 & 0.25661 & 2012 & 5 & Long B \\
\hline Vasco & 16 & 2 & 8 & 2 & 0.26481 & 2013 & 11 & Long A (PB) \\
\hline Thaibonnet & 18 & 4 & 13 & 4 & 0.33096 & 1992 & 535 & Long B \\
\hline Giglio & 18 & 2 & 4 & 1 & 0.21769 & 2011 & 319 & Long B \\
\hline Sole CL & 19 & 3 & 9 & 3 & 0.31081 & 2012 & 260 & Round \\
\hline Fedra & 20 & 6 & 12 & 6 & 0.36305 & 2012 & 3 & Long A (IC) \\
\hline Brezza & 20 & 3 & 9 & 2 & 0.30827 & 2013 & 3 & Long B \\
\hline Tigre & 20 & 6 & 11 & 3 & 0.35467 & 2012 & 4 & Long B \\
\hline Ercole & 23 & 7 & 5 & 2 & 0.30902 & 2005 & 98 & Long A (PB) \\
\hline CL12 & 23 & 5 & 5 & 2 & 0.30834 & 2012 & 1238 & Round \\
\hline Ellebi & 23 & 7 & 4 & 3 & 0.30111 & 2007 & 1147 & Long B \\
\hline SP55 & 25 & 8 & 13 & 6 & 0.41139 & 2008 & 164 & Round \\
\hline Castore & 28 & 6 & 9 & 5 & 0.35553 & 2013 & - & Round \\
\hline Roma & 29 & 7 & 20 & 4 & 0.47920 & 1967 & 3840 & Long A (IC) \\
\hline Yume & 29 & 7 & 14 & 2 & 0.39338 & 2007 & 544 & Round \\
\hline Fast & 30 & 4 & 19 & 4 & 0.46670 & 2012 & 4 & Long B \\
\hline Luna CL & 30 & 4 & 11 & 3 & 0.41146 & 2011 & 7832 & Long A (PB) \\
\hline
\end{tabular}

${ }^{a}$ Mean calculated after angular transformation. $\mathrm{LSD}=0.39964$

${ }^{\mathrm{b}}$ Italian Cultivated Area in 2012. Data provided by Ente Nazionale Risi

symptoms (Fig. 2). This incidence reduction is stable and it is verified in each resistance class (Fig. 3). The interaction effect between treatment and year was nonsignificant while interaction effect between cultivar and treatment was highly significant $(p<0.001)$.

\section{Discussion and conclusions}

The relative field resistance of Italian rice cultivars to neck blast disease is not well known; for this reason, cultivars were chosen among those traditionally most important registered in National list before 2005 (Tamborini and Legnani 2005), and all cultivars registered from 2005 to 2013 (SIAN 2013).

Recent studies identified the presence of resistance genes to the three lineages of P. oryzae reported in Italy. Among the cultivars considered in the present study, 42 have been characterized for resistance genes Pi-ta, Pi-B, $\mathrm{Pk}^{\mathrm{h}}$ and Pi-z (Gironi et al. 2010), which have been proven to determinate complete resistance to all (Pi-ta and $\mathrm{Pi}-\mathrm{b}$ ) or most (Pi-kh and Pi-z) of Italian strains (Roumen et al. 1997). Screening results showed that 38 cultivars have no resistance genes, while four cultivars have one or two resistance genes: Arsenal and Atlantis (Pi-z and Pi-k $\left.{ }^{\mathrm{h}}\right)$, Libero $\left(\mathrm{Pi}-\mathrm{k}^{\mathrm{h}}\right)$, Augusto (Piz) (Gironi et al. 2010). Arsenal, Atlantis and Libero resulted resistant in our test, instead of Augusto, which appeared to be MS (33\% of infected panicles). Moreover, Faivre-Rampant et al. (2011) tested the resistance of several varieties to leaf-blast using nursery method and artificial inoculation with three isolates representative of the three lineages of $M$. oryzae reported in Italy (Roumen et al. 1997). For varieties tested in both this study and Faivre-Rampant et al. trials there's generally a good correspondence, despite the different method of resistance class assignment. The majority of varieties that in Faivre-Rampant's study showed different degrees of resistance to the three different pathotypes have at least a response consistent with that in our study. 
Table 4 List of Moderately Susceptible varieties (MS), 30.1-50.0\% incidence of panicles showing neck blast symptoms; results expressed as average of incidence and severity score assessed in 2011 and 2012 in treated and untreated plots

\begin{tabular}{|c|c|c|c|c|c|c|c|c|}
\hline \multirow[t]{2}{*}{ Cultivar } & \multicolumn{2}{|l|}{ Untreated } & \multicolumn{2}{|l|}{ Treated } & \multirow{2}{*}{$\begin{array}{l}\text { Mean } \\
\text { Incidence }^{a}\end{array}$} & \multirow{2}{*}{$\begin{array}{l}\text { Registration } \\
\text { year }\end{array}$} & \multirow{2}{*}{$\begin{array}{l}2012 \\
\text { area } \\
\text { (ha) }\end{array}$} & \multirow{2}{*}{$\begin{array}{l}\text { Grain } \\
\text { shape }\end{array}$} \\
\hline & $\begin{array}{l}\text { Incidence } \\
(\%)\end{array}$ & $\begin{array}{l}\text { Severity } \\
(0-9)\end{array}$ & $\begin{array}{l}\text { Incidence } \\
(\%)\end{array}$ & $\begin{array}{l}\text { Severity } \\
(0-9)\end{array}$ & & & & \\
\hline Teti & 31 & 6 & 9 & 4 & 0.40275 & 2013 & 2 & Long A (PB) \\
\hline SIS R215 & 31 & 4 & 10 & 3 & 0.41730 & 2003 & 40 & Long A (PB) \\
\hline Augusto & 33 & 7 & 12 & 4 & 0.44234 & 2002 & 4610 & Long A (PB) \\
\hline Antares & 33 & 6 & 11 & 3 & 0.40864 & 2010 & 158 & Long A (PB) \\
\hline Rombo & 34 & 4 & 14 & 5 & 0.44037 & 2011 & 1 & Long A (PB) \\
\hline Ronaldo & 34 & 5 & 8 & 2 & 0.40118 & 2010 & 5844 & Long A (PB) \\
\hline Centro & 35 & 5 & 7 & 2 & 0.39988 & 2012 & 131 & Long B \\
\hline Onice & 35 & 7 & 16 & 5 & 0.50558 & 2011 & 372 & Long A (PB) \\
\hline Samba & 35 & 5 & 20 & 5 & 0.52710 & 2008 & 96 & Long A (IC) \\
\hline Sfera & 38 & 6 & 6 & 2 & 0.40159 & 2012 & 36 & Round \\
\hline Gloria & 38 & 6 & 19 & 4 & 0.51846 & 2010 & 486 & Long A (IC) \\
\hline Corimbo & 38 & 6 & 19 & 5 & 0.52683 & 2013 & 1 & Long B \\
\hline Agata & 39 & 7 & 6 & 3 & 0.40720 & 2012 & 6 & Round \\
\hline Cerere & 39 & 5 & 14 & 2 & 0.48953 & 2009 & 919 & Round \\
\hline Ninfa & 40 & 7 & 6 & 2 & 0.39387 & 2012 & 0.2 & Long B \\
\hline Bacco & 41 & 7 & 24 & 5 & 0.57906 & 2011 & 80 & Long A (IC) \\
\hline Lince & 41 & 5 & 20 & 4 & 0.51098 & 2011 & 510 & Long A (PB) \\
\hline Virgo & 41 & 6 & 21 & 6 & 0.57858 & 2011 & 939 & Round \\
\hline Aiace & 41 & 6 & 27 & 5 & 0.59743 & 2002 & 933 & Long A (PB) \\
\hline Ducato & 44 & 6 & 18 & 5 & 0.57641 & 2011 & 196 & Round \\
\hline Carnaroli & 44 & 8 & 20 & 5 & 0.57356 & 1983 & 9003 & Long A (IC) \\
\hline S. Andrea & 44 & 7 & 20 & 5 & 0.57803 & 1974 & 10,796 & Long A (IC) \\
\hline Opale & 45 & 7 & 23 & 4 & 0.56591 & 2008 & 1688 & Long A (PB) \\
\hline Crono & 46 & 7 & 14 & 3 & 0.53788 & 2010 & 584 & Medium \\
\hline Scudo & 46 & 5 & 12 & 5 & 0.52528 & 2005 & 54 & Long B \\
\hline Proteo & 46 & 7 & 13 & 3 & 0.54580 & 2013 & 1 & Long A (PB) \\
\hline Galileo & 48 & 7 & 21 & 6 & 0.61663 & 2002 & 4228 & Long A (IC) \\
\hline Urano & 48 & 6 & 8 & 3 & 0.50166 & 2009 & 499 & Long B \\
\hline Medea & 48 & 5 & 19 & 3 & 0.57555 & 2013 & 1 & Medium \\
\hline Karnak & 48 & 7 & 14 & 4 & 0.52222 & 2002 & 7796 & Long A (IC) \\
\hline Puma & 48 & 6 & 21 & 4 & 0.61499 & 2011 & 2981 & Long A (PB) \\
\hline
\end{tabular}

${ }^{a}$ Mean calculated after angular transformation. $\mathrm{LSD}=0.39964$

${ }^{\mathrm{b}}$ Italian Cultivated Area in 2012. Data provided by Ente Nazionale Risi

Where the response within the two studies is very different, it could be likely the lack of complete correspondence on disease severity between evaluations made at nursery stage and field evaluations during ripening stage. This can clearly be observed on Augusto and Argo cultivars, that resulted in resistance to leaf blast (Faivre-Rampant et al. 2011) while being susceptible to neck blast. It is also possible to observe the opposite; Orione and Roma are reported to be highly susceptible to leaf blast while being moderately resistant to neck blast disease. Finally, the mismatch in results on neck and leaf blast resistance could be explained thanks to new advances in molecular characterization of M. oryzae. In fact, the analysis of more than 200 strains collected in Lombardy Region suggests the 
Table 5 List of Susceptible varieties (S), 50.1-100.0\% incidence of panicles showing neck blast symptoms; results expressed as average of incidence and severity score assessed in 2011 and 2012 in treated and untreated plots

\begin{tabular}{|c|c|c|c|c|c|c|c|c|}
\hline \multirow[t]{2}{*}{ Cultivar } & \multicolumn{2}{|l|}{ Untreated } & \multicolumn{2}{|l|}{ Treated } & \multirow{2}{*}{$\begin{array}{l}\text { Mean } \\
\text { Incidence }^{\mathrm{a}}\end{array}$} & \multirow{2}{*}{$\begin{array}{l}\text { Registration } \\
\text { year }\end{array}$} & \multirow{2}{*}{$\begin{array}{l}2012 \\
\text { area } \\
\text { (ha) }\end{array}$} & \multirow{2}{*}{$\begin{array}{l}\text { Grain } \\
\text { shape }\end{array}$} \\
\hline & $\begin{array}{l}\text { Incidence } \\
(\%)\end{array}$ & $\begin{array}{l}\text { Severity } \\
(0-9)\end{array}$ & $\begin{array}{l}\text { Incidence } \\
(\%)\end{array}$ & $\begin{array}{l}\text { Severity } \\
(0-9)\end{array}$ & & & & \\
\hline Centauro & 51 & 6 & 14 & 5 & 0.56591 & 2002 & 27,290 & Round \\
\hline Scirocco & 51 & 7 & 9 & 3 & 0.51810 & 2004 & 11 & Long A (PB) \\
\hline Argo & 53 & 7 & 14 & 4 & 0.57152 & 1978 & 309 & Round \\
\hline Febo & 53 & 7 & 21 & 5 & 0.60651 & 2012 & 1 & Long B \\
\hline Dardo & 55 & 8 & 34 & 5 & 0.74947 & 2010 & 8052 & Long A (PB) \\
\hline Neve & 55 & 8 & 34 & 5 & 0.73916 & 2013 & 24 & Long A (IC) \\
\hline Musa & 55 & 6 & 34 & 4 & 0.72305 & 2011 & 202 & Medium \\
\hline Meco & 56 & 7 & 13 & 5 & 0.57720 & 2012 & 90 & Long A (PB) \\
\hline Brio & 56 & 6 & 22 & 3 & 0.69037 & 2005 & 3401 & Round \\
\hline Albatros & 59 & 6 & 14 & 3 & 0.58685 & 2000 & 22 & Long B \\
\hline Gladio & 59 & 8 & 32 & 4 & 0.73287 & 1998 & 11,719 & Long B \\
\hline Selenio & 59 & 7 & 20 & 2 & 0.64397 & 1987 & 13,696 & Round \\
\hline Baldo & 59 & 8 & 30 & 6 & 0.72811 & 1977 & 7705 & Long A (IC) \\
\hline Ulisse & 60 & 8 & 17 & 6 & 0.62596 & 2007 & 2603 & Long A (IC) \\
\hline Carnise & 60 & 7 & 28 & 6 & 0.70952 & 2008 & 1382 & Long A (IC) \\
\hline Flipper & 61 & 8 & 33 & 5 & 0.74783 & 1997 & 228 & Medium \\
\hline Nuovo Maratelli & 61 & 7 & 39 & 5 & 0.75412 & 2000 & 124 & Medium \\
\hline Sirio CL & 63 & 8 & 21 & 5 & 0.69266 & 2009 & 17,739 & Long B \\
\hline Volano & 63 & 8 & 40 & 7 & 0.80192 & 1972 & 19,550 & Long A (IC) \\
\hline Eridano & 63 & 6 & 33 & 3 & 0.77753 & 2012 & 40 & Round \\
\hline Nembo & 65 & 7 & 33 & 5 & 0.75738 & 1999 & 2346 & Long A (PB) \\
\hline Lido & 68 & 7 & 28 & 6 & 0.74660 & 1976 & - & Medium \\
\hline Ariete & 69 & 7 & 33 & 4 & 0.79456 & 1985 & 311 & Long A (PB) \\
\hline CRLB1 & 70 & 8 & 48 & 6 & 0.92378 & 2007 & 540 & Long B \\
\hline Carmen & 71 & 7 & 34 & 5 & 0.82326 & 2005 & 17 & Long A (IC) \\
\hline Creso & 73 & 7 & 15 & 5 & 0.69087 & 2004 & 1717 & Long A (PB) \\
\hline Delfino & 76 & 8 & 30 & 6 & 0.81364 & 2001 & 362 & Long $\mathrm{A}(\mathrm{PB})$ \\
\hline Eurosis & 76 & 5 & 44 & 6 & 0.93772 & 2002 & 282 & Long A (PB) \\
\hline Balilla & 76 & 7 & 45 & 6 & 0.91397 & 1967 & 3649 & Round \\
\hline Presto & 78 & 6 & 29 & 4 & 0.82787 & 2012 & - & Long A (PB) \\
\hline Nerone & 79 & 8 & 26 & 5 & 0.85909 & 2009 & 14 & Long A (PB) \\
\hline Loto & 80 & 8 & 25 & 6 & 0.83118 & 1988 & 6135 & Long A (PB) \\
\hline Luxor & 81 & 8 & 41 & 7 & 0.93675 & 2008 & 60 & Long A (PB) \\
\hline Arborio & 83 & 8 & 46 & 7 & 0.97584 & 1967 & 867 & Long A (IC) \\
\hline Sprint & 88 & 8 & 73 & 6 & 1.19096 & 2002 & 203 & Long B \\
\hline Elio & 91 & 6 & 36 & 4 & 0.95507 & 1985 & 173 & Round \\
\hline Deneb & 95 & 9 & 70 & 8 & 1.21357 & 2007 & 41 & Medium \\
\hline Carnise Precoce & 96 & 8 & 50 & 8 & 1.12671 & 2008 & 809 & Long A (IC) \\
\hline Ambra & 98 & 9 & 46 & 6 & 1.11681 & 1999 & 208 & Round \\
\hline Vialone nano & 98 & 9 & 64 & 7 & 1.22623 & 1967 & 4140 & Medium \\
\hline
\end{tabular}

${ }^{a}$ Mean calculated after angular transformation. $\mathrm{LSD}=0.39964$

${ }^{\mathrm{b}}$ Italian Cultivated Area in 2012. Data provided by Ente Nazionale Risi 


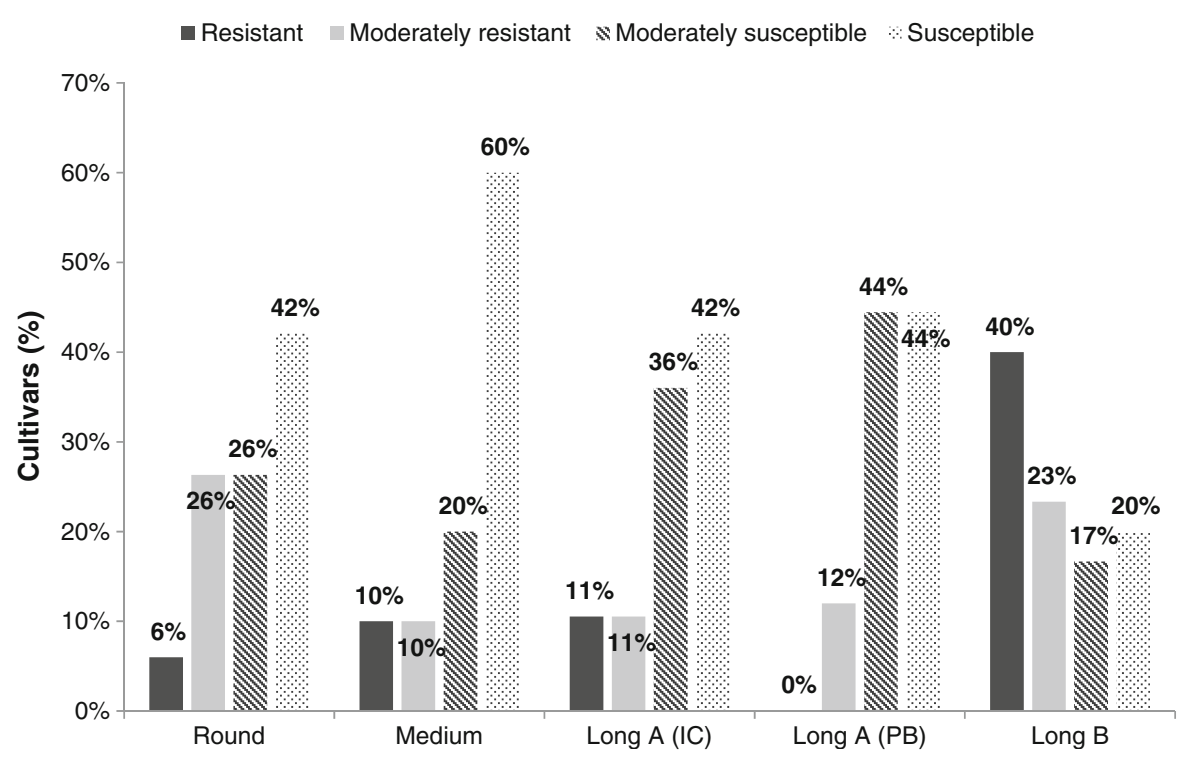

Fig. 1 Percentage of Resistant (R), Moderately Resistant (MR), Moderately Susceptible (MS) or Susceptible (S) varieties belonging at each grain type

presence of new haplotypes, different from those reported by Roumen in 1997 (Abbruscato et al. 2014).

Sixteen varieties out of 105 exhibited incidence lower than $15 \%$; since we worked under favourable environmental conditions for the pathogen, they were classified as Resistant. Medium and Long A for internal consumption grain shape varieties (to which belong most traditional cultivars) were determined to be highly susceptible to the disease with $80 \%$ and $78 \%$ of MS + S cultivars respectively. This result agrees with what is commonly reported; in fact, traditional cultivars, are preferred in the Italian market for their qualitative and organoleptic characteristics despite their high susceptibility to the disease and, for some varieties, despite their agronomic problems (long stem, late time of maturity, difficulties on red rice control). High susceptibility of

Table 6 Evolution of incidence and severity of symptom of neck blast disease in tested cultivars, according to the year of registration in National list; data collected in untreated block

\begin{tabular}{lll}
\hline Years of subscription & Incidence (\%) & Severity (0-9) \\
\hline $1960-1969$ & 71 & 8 \\
$1970-1979$ & 57 & 7 \\
$1980-1989$ & 69 & 7 \\
$1990-1999$ & 60 & 7 \\
$2000-2009$ & 50 & 6 \\
$2010-2013$ & 30 & 5 \\
\hline
\end{tabular}

some of these cultivars can also be due to the fact that they had been bred at the beginning of last century for cultivation with reduced nitrogen rates than those currently suggested.

Type of incidence and severity in cultivars of recent introduction are less severe. This can be due to different factors. First, one of the main goals in Italian rice breeding has always been to select varieties with genetic resistance to neck blast disease; second, after 1990 in Italy were introduced varieties from the US with good blast disease resistance, that were integrated in rice breeding programs (Faivre-Rampant et al. 2011); third, cultivars registered in National list in 1967 (the year of constitution of the official National list) were actually selected between 1920 and 1940 (Tamborini et al. 2008) and in almost a century of cultivation the pathogen could have overcome host resistance. Moreover, the ability of the fungus to mutate and quickly overcome host resistances is well known and is a major problem for rice breeders (Bonman 1992; Araujo et al. 2000; Conaway-Bormans et al. 2003; Faivre-Rampant et al. 2011).

Tricyclazole was effective in reducing the neck blast disease. For Moderately Susceptible or Susceptible cultivars, a single treatment reduced incidence and severity of disease but the infection was still high after the treatment, confirming that a single treatment in presence of conductive conditions and susceptible cultivars is not enough to control the disease (Moletti et al. 1988). In 


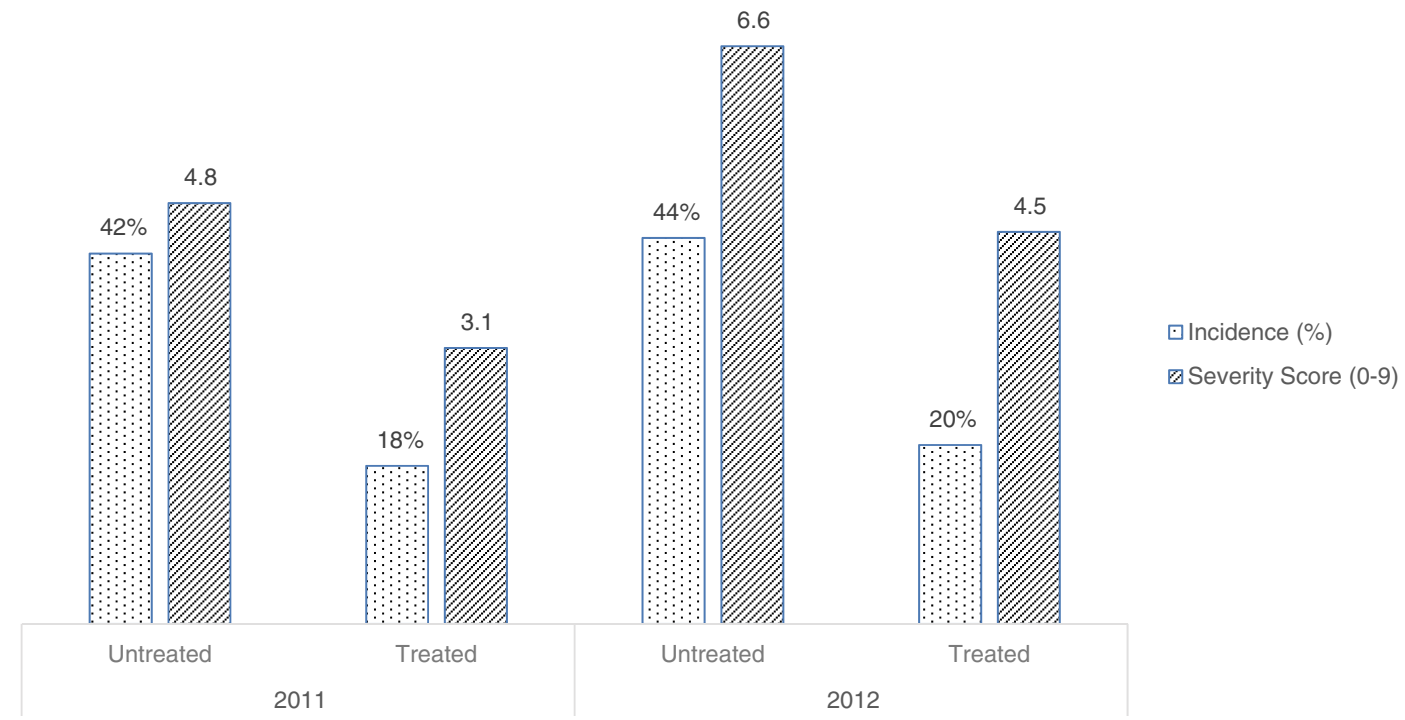

Fig. 2 Incidence of infected panicles (\%) and severity score (0-9) observed in 2011 and 2012; results expressed as average of data collected in treated and untreated plots

such conditions, good agronomical practices (especially application of reduced nitrogen rates) are recommended (Bonman and Garrity 1992; Webster and Gunnell 1992; Long et al. 2000; Ballini et al. 2013). In Italy, under favourable conditions for blast disease, cultivar classified as Resistant could be grown even without fungicide protection; this group consists mainly of Long B grain shape varieties (14 out of 16). Under favourable conditions, all cultivars belonging to MR group could be cultivated without risk of high yield losses if a reduced nitrogen rate or fungicide treatment is applied. For MS cultivar reduced nitrogen supply and fungicide treatment should be carefully considered by the grower. On the other hand, S cultivars should be avoided for cultivation under favourable conditions unless supplied nitrogen is reduced and at least one fungicide treatment is applied. It is impossible to suggest the best cultivar to be grown in favourable condition for neck blast disease but

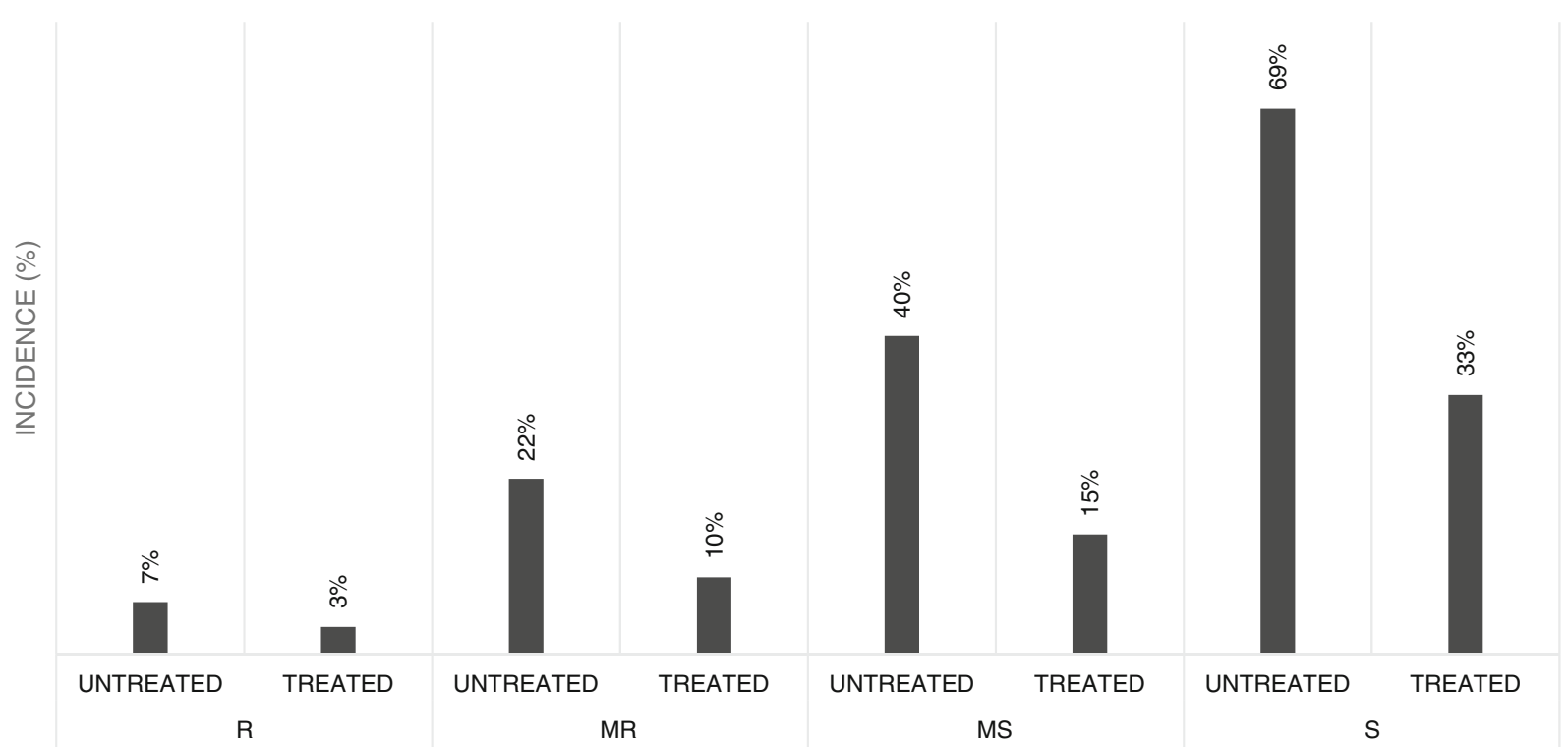

Fig. 3 Mean of incidence (\%) among the different resistance classes compared in treated and untreated plots 
following the above recommendations combined with other fundamental cultivar parameters, such as time of maturity, grain and milling yield, and considering market price, farmers could make the best choice in their situation.

Tricyclazole still remains a valuable tool to control the disease especially considering that, in 2012 , the $80 \%$ of the Italian rice area is cultivated with Moderately Susceptible or Susceptible cultivars. Furthermore, given the strong ability of the fungus to overcome host plant resistance, tricyclazole is even more useful especially for varieties that have high commercial value. On the other hand, an eventual genetic resistance would constitute a valid alternative both from economic and environmental point of view.

Considering that there isn't always a correlation between symptoms observed on leaves and then on panicles and despite the huge amount of study on resistance genes, host-pathogen interaction, selection of resistant cultivar (Dean et al. 2005; Jia et al. 2000, 2009; Bagnaresi et al. 2012; Campos-Soriano et al. 2013; Miah et al. 2013; Wu et al. 2013) it is still important to confirm in-field the expression of any possible resistance on the basis of the environment and agricultural techniques used. The availability of data about the field resistance is an important tool for researchers, breeders and growers, combining scientific value with impact in applications. At global level many researches are focused on how climate changes can impact on the future ability of agriculture to provide food and feed (Climate Change Position Statement Working Group 2011). In this sector, the forecast models play a fundamental role, but the improvement of existing models needs precise information such as varietal field resistance to main diseases that cause yield losses. Breeders can use this information to focus their research of new resistant varieties, considering that in Italian rice growing area the main blast symptom concern the panicle, instead of other environmental condition, where the leaf blast is the most spread symptom. The impact of this work in application is evident, as the choice a variety to be grown is driven by many factors, at the base of which there is always the goal of an economic return. Losses caused by diseases result in economic losses, so the variety choice must be done consciously, even considering the economic impact that diseases may have, in order to prevent damages and to adopt any possible countermeasures.
Acknowledgments The authors thank Dario Sacco for support on data analysis.

This work was supported by DOW Agrosciences Italia s.r.1.

Open Access This article is distributed under the terms of the Creative Commons Attribution License which permits any use, distribution, and reproduction in any medium, provided the original author(s) and the source are credited.

\section{References}

Abbruscato, P., Crispino, L., Menin, B., Piffanelli, P., Biazzi, E., Carelli, M., et al. (2014). Sviluppo di mezzi a basso impatto ambientale di biocontrollo dell'agente del brusone. In Biogesteca (Ed.), Quaderno Biocontrollo (pp. 17-44). Milano.

Aram, P., Nadali, B. J., Nadali, B., \& Gorbanali, N. (2013). Leaf blast resistance of rice different genotypes in blast nursery. International Journal of Agriculture and Crop Sciences, 5(12), 1307-1313.

Araujo, L. G., Prabhu, A. S., \& Freire, A. D. (2000). Development of blast resistant somaclones of the upland rice cultivar Araguaia. Pesquisa Agropecuária Brasileira, 35(2), 357367.

Astolfi, G. (1828). Congetture dell'ingegnere Giuseppe Astolfi ... sopra la malattia del brusone che infesta il riso e i rimedi che possono prevenirla e sopra alcuni metodi d'avvicendamento che possono per le risaje utilmente praticarsi. Bologna: Tipografia Marsigli.

Bagnaresi, P., Biselli, C., Orrù, L., Urso, S., Crispino, L., Abbruscato, P., et al. (2012). Comparative transcriptome profiling of the early response to Magnaporthe oryzae in durable resistant vs susceptible rice (Oryza sativa L.) genotypes. PloS One, 7(12), e51609.

Ballini, E., Nguyen, T. T., \& Morel, J.-B. (2013). Diversity and genetics of nitrogen-induced susceptibility to the blast fungus in rice and wheat. Rice, $6(1), 32$.

Biloni, M., \& Lorenzi, E. (2002). Relation between leaf and neck blast resistance in Italian rice varieties. Atti delle Giornate Fitopatologiche.

Bonman, J. (1992). Durable resistance to rice blast diseaseenvironmental influences. In Breeding for Disease Resistance (pp. 115-123): Springer.

Bonman, J., \& Garrity, D. (1992). Effects of nitrogen timing and split application on blast disease in upland rice. Plant Disease, 76(4), 384-389.

Buffa, G. (2000). Una guerra lunga 200 anni. Il Risicoltore, 43(7), 8.

Campos-Soriano, L., Vale, G., Lupotto, E., \& San Segundo, B. (2013). Investigation of rice blast development in susceptible and resistant rice cultivars using a gfp-expressing Magnaporthe oryzae isolate. Plant Pathology, 62(5), 10301037. doi:10.1111/ppa.12023.

Casati, D. (2013). Il mercato del riso e le sue prospettive. Dal seme, $\operatorname{VIII}(1), 40-47$.

Climate Change Position Statement Working Group (2011). Position statement on climate change. Working Group Rep. ASA, CSSA, and SSSA, Madison. 
Commission, E. (2013). Common catalogue of varieties of agricultural plant species 32nd complete edition. Official Journal of the European Union.

Conaway-Bormans, C. A., Marchetti, M. A., Johnson, C. W., McClung, A. M., \& Park, W. D. (2003). Molecular markers linked to the blast resistance gene Pi-z in rice for use in markerassisted selection. Theoretical and Applied Genetics, 107(6), 1014-1020. doi:10.1007/s00122-003-1338-5.

Cortesi, P., \& Giuditta, L. (2003). Epidemiologia dell'elmintosporiosi e del brusone e difesa del riso. Informatore Fitopatologico, 53(2), 41-51.

Couch, B. C., \& Kohn, L. M. (2002). A multilocus gene genealogy concordant with host preference indicates segregation of a new species, Magnaporthe oryzae, from M. grisea. Mycologia, 94(4), 683-693. doi:10.2307/3761719.

Dean, R. A., Talbot, N. J., Ebbole, D. J., Farman, M. L., Mitchell, T. K., Orbach, M. J., et al. (2005). The genome sequence of the rice blast fungus Magnaporthe grisea. Nature, 434(7036), 980-986.

Di Tullio, E., \& Baldi, S. (2011). La diffusione dei diversi sistemi di difesa dal brusone nella risicoltura italiana. In AGRA (Ed.), Il ruolo economico del triciclazolo nella risicoltura italiana (pp. 189). Roma: Das Print.

Ente Nazionale Risi (2013). Superfici coltivate. http://www. enterisi.it/servizi/seriestoriche/superfici_fase01.aspx. Accessed 15 December 2013.

Faivre-Rampant, O., Bruschi, G., Abbruscato, P., Cavigiolo, S., Picco, A. M., Borgo, L., et al. (2011). Assessment of genetic diversity in Italian rice germplasm related to agronomic traits and blast resistance (Magnaporthe oryzae). Molecular Breeding, 27(2), 233-246. doi:10.1007/s11032-010-9426-0.

Faivre-Rampant, O., Geniès, L., Piffanelli, P., \& Tharreau, D. (2013). Transmission of rice blast from seeds to adult plants in a non-systemic way. Plant Pathology, 62(4), 879-887.

Froyd, J., Paget, C., Guse, L., Dreikorn, B., \& Pafford, J. (1976). Tricyclazole: a new systemic fungicide for control of Pyricularia oryzae on rice. Phytopathology, 66(1), 135-131.

Gallo, A. (1775). Le vinti giornate dell'agricoltura, et de'piaceri della villa: Appresso Ghirardo Imberti.

Gironi, R., Cormegna, M., Piffanelli, P., Borgo, L., Carnia, A., Sodano, A., et al. (2010). Utilizzo di marcatori molecolari per identificare geni di resistenza a Pyricularia grisea. In R. Lombardia (Ed.), Metodiche molecolari per la valorizzazione delle varietà di riso coltivate in Lombardia (Vol. 123, pp. 3337, Quaderni della Ricerca).

IRRI (2002). Standard Evaluation System for Rice (SES). (4 ed., pp. 15-16). Los Banos. Philippines: International Rice Research Institute (IRRI).

IRRI (2013). Rice Blast. http://www.knowledgebank.irri.org/ipm/ rice-blast.html. Accessed 15 October 2013.

Jia, Y., McAdams, S. A., Bryan, G. T., Hershey, H. P., \& Valent, B. (2000). Direct interaction of resistance gene and avirulence gene products confers rice blast resistance. The EMBO Journal, 19(15), 4004-4014.

Jia, Y., Lee, F. N., \& McClung, A. (2009). Determination of Resistance Spectra of the Pi-ta and Pi-k Genes to US Races of Magnaporthe oryzae causing rice blast in a recombinant inbred line population. Plant Disease, 93(6), 639-644. doi:10.1094/pdis-93-6-0639.

Long, D. H., Lee, F. N., \& TeBeest, D. O. (2000). Effect of nitrogen fertilization on disease progress of rice blast on susceptible and resistant cultivars. Plant Disease, 84(4), 403-409.

Maciel, J. L. N. (2011). Magnaporthe oryzae, the blast pathogen: current status and options for its control. In D. Hemming (Ed.), Plant Sciences Reviews 2011 (p. 264). Bangalore: CABI.

Marchetti, M. (1983). Dilatory resistance to rice blast in USA rice. Phytopathology, 73(5), 645-649.

Miah, G., Rafii, M. Y., Ismail, M. R., Puteh, A. B., Rahim, H. A., Asfaliza, R., et al. (2013). Blast resistance in rice: a review of conventional breeding to molecular approaches. Molecular Biology Reports, 40(3), 2369-2388. doi:10.1007/s11033-0122318-0.

Moletti, M., Giudici, M. L., Nipoti, E., \& Villa, B. (1988). Prove di lotta chimica contro il brusone del riso in Italia. Informatore Fitopatologico, 38(3), 41-48.

Puri, K. D., Shrestha, S. M., Chhetri, G. B. K., \& Joshi, K. D. (2009). Leaf and neck blast resistance reaction in tropical rice lines under green house condition. Euphytica, 165(3), 523532.

Re, G. F. (1826). Confutazione delle varie ipotesi, sul brusone del riso emesse dai dottori Rocco Ragazzoni, e Demetrio Roncia: da Carlo Sylva.

Rodolfi, M., Picco, A. M., Confalonieri, R., \& Biloni, M. (2006). Simulazione di avversità biotiche in modelli colturali: un esempio per Riso e Brusone. Italian Journal of Agrometeorology, 11, 26-27.

Roumen, E., Levy, M., \& Notteghem, J. L. (1997). Characterisation of the European pathogen population of Magnaporthe grisea by DNA fingerprinting and pathotype analysis. European Journal of Plant Pathology, 103(4), 363371.

Shafaullah, Khan, M. A., Khan, N. A., Salim-il-Yasin, \& Mahmood, Y. (2011). Response of rice germplasm to blast disease under field conditions. Pakistan Journal of Phytopathology, 23(1), 52-55.

SIAN (2013). Registri delle varietà vegetali. http://www.sian.it/ regivis. Accessed 10 October 2013.

Tamborini, L., \& Legnani, C. (2005). Le varietà di riso coltivate in Italia, caratteristiche e criteri di scelta. Vercelli: Gallo Arti Grafiche.

Tamborini, L., Lupotto, E., Greppi, D., \& Cavigiolo, S. (2008). Le varietà di riso coltivate in Italia nella prima metà del XX secolo. Vercelli: Gallo Arti Grafiche.

TeBeest, D. O., Guerber, C., \& Ditmore, M. (2007). Rice blast. The Plant Health Instructor. http://www.apsnet.org/edcenter/ intropp/lessons/fungi/ascomycetes/Pages/RiceBlast.aspx. Accessed October 2013.

Webster, R. K., \& Gunnell, P. S. (1992). Compendium of rice diseases. St Paul: American Phytopathological Society.

Wu, Y., Bao, Y., Xie, L., Su, Y., Chu, R., He, W., et al. (2013). Fine mapping and identification of blast resistance gene $P i-h k l$ in a broad-spectrum resistant japonica rice landrace. Phytopathology, 103(11), 1162-1168. doi:10.1094/phyto-0213-0044-r. 